\title{
Introduction of household biogas digesters in rural farming households of the Maluti-a-Phofung municipality, South Africa
}

\author{
K.M. Nape ${ }^{1}$, P. Magama ${ }^{2}$, M.E. Moelets $i^{1,3^{*}}$, M.I. Tongwane ${ }^{1}$, P.M. Nakana ${ }^{1}$, \\ V.K. Mliswa ${ }^{1}$, M. Motsepe ${ }^{4}$, S. Madikiza ${ }^{4}$ \\ 1. Agricultural Research Council - Institute for Soil, Climate and Water, South Africa \\ 2. Agricultural Research Council - Institute for Agricultural Engineering, South Africa \\ 3. Risks and Vulnerability Assessment Centre, University of Limpopo, South Africa \\ 4. Department of Agriculture, Forestry and Fisheries, Directorate: Climate Change and Disaster Management, \\ South Africa \\ K.M. Nape: https://orcid.org/0000-0003-4574-4225; P. Magama: https://orcid.org/0000-0002-5058-7407; \\ M.E. Moeletsi: https://orcid.org/0000-0003-3932-5569; M.I. Tongwane https://orcid.org/0000-0002-8003-909X; \\ P.M. Nakana https://orcid.org/0000-0003-4521-7310; V.K. Mliswa https://orcid.org/0000-0003-3651-1366; \\ M.I. Motsepe https://orcid.org/0000-0002-1950-9320; S. Madikiza https://orcid.org/0000-0002-7610-5381
}

\begin{abstract}
The study aimed to introduce biogas as an alternative source of energy for rural cattle farmers in the Malutia-Phofung municipality in the Free State Province, South Africa. To augment the rural farming community's adoption of the biodigester technology the following initiatives were undertaken: (i) a situational analysis (or diagnostic survey); (ii) training on biogas production in an integrated crop-livestock-bioenergy system; (iii) installation of the biodigesters; and (iv) monitoring and evaluation of the biogas production. Results on the diagnostic survey showed that the main source of energy for cooking was wood in all the farms and availability of water was not a constraint. Prefabricated biodigesters of $6 m^{3}-12 m^{3}$ were installed in all the households and, after continual feeding of the units with cattle dung, the production of biogas increased gradually. Monitoring of biogas production showed that, in two-thirds of the households, $80 \%$ of their cooking needs were met in summer, while in winter biogas production was minimal due to extremely cold weather. Challenges faced included non-adherence to a feeding regime - resulting in a blockage of the biodigester and lack of feeding. Generally, farmers in the study area showed a high appreciation of the biodigester technology.
\end{abstract}

Keywords: Anaerobic digestion; biogas technology; situational analysis; training; monitoring and evaluation

Journal of Energy in Southern Africa 30(2): 28-37

DOI: http://dx.doi.org/10.17159/2413-3051/2019/v30i2a5885

This work is licensed under a Creative Commons Attribution-ShareAlike 4.0 International License Published by the Energy Research Centre, University of Cape Town ISSN: 2413-3051 https://journals. assaf.org.za/jesa

Sponsored by the Department of Science and Technology

\footnotetext{
* Corresponding author: Tel:+27 (0)12 310 2537; email:

moeletsim@arc.agric.za, mmoeletsi@hotmail.com
} 


\section{Introduction}

Rising energy costs, increasing energy demand, diminishing fossil fuel reserves and increasing greenhouse gas emissions are some of the challenges that many governments face when energising rural communities (UNCTD, 2010). Renewable energy is increasingly gaining support as an alternative and sustainable way of providing much-needed energy in rural areas, combating climate change and improving rural livelihoods (UNCTD, 2010; OECD, 2012). Biogas technology is one of the renewable energy opportunities that are well accepted in most countries (APCAEM, 2007). Biogas is produced when organic matter (abattoir waste, animal manure, kitchen waste or agricultural residue) is decomposed in an anaerobic environment by a chain of micro-organisms (Warget, 2009). The attributes of the biogas technology go beyond the production of gas, with added benefits like the conversion of organic waste to high-quality fertiliser and sanitation improvements (APCAEM, 2007).

Apart from industrial initiatives, there have been several small-scale renewable energy projects globally that aim to provide energy to communities. One of the advantages of biogas technology is its adaptability at a small-scale level. Hence, this technology can provide a solution to an assortment of users at different resource accessibility and affordability levels. Biogas is considered amongst the cheapest forms of renewable energy in rural areas of developing countries, but its initial capital cost is mostly unaffordable for people living there (APCAEM, 2007; Roubík et al., 2018). Countries like China, India, Sudan, Ghana and Rwanda have successfully implemented biodigester programmes providing energy to multitudes of people (Bensah and Brew-Hammond, 2010; Bond and Templeton, 2011; Rupf et al., 2015). Small-scale biodigesters have been deployed in several countries and the technology has been well adopted in Asian countries, with over 15 million households using biogas in China (APCAEM, 2007; Bond and Templeton, 2011; Rupf et al., 2015). This high number of biogas users in Asia is mainly due to the many government interventions through regulations, policies and investment support. Generally in Africa, the adoption of biogas technology has not been optimal, even though Africa experiences major challenges related to energy availability in both rural and urban areas. The failure of African governments to adopt this technology is due to the lack of energy policies that support biogas technologies or renewable energy initiatives, and a lack of substantial investments in renewable energy (Bensah and Brew-Hammond, 2010).

South Africa has slowly started to embrace renewable energy through its development of a renewable energy policy (DME, 2002; Sibisi and
Green, 2005). The introduction of the Renewable Energy Independent Power Producer Procurement Programme in 2011 is one of the major initiatives in South Africa, with massive investment in renewable energy projects (Eberhard et al., 2014; Yuen, 2014; DME, 2015). South Africa established a target for renewable energy production at 10000 GWh by 2013 and another target is to generate 20000 MWh of renewable energy by 2030 (DME, 2002; DOP, 2012). The country has since catapulted into a world leadership position with respect to renewable energy investment and development (DME, 2015). Large investments in renewable energy were made particularly in the hydropower generation and solar-PV systems. These technologies are among the few that are thought to bring an extensive contribution to the renewable energy supply of South Africa. The White Paper on renewable energy recognises the potential of using the manure and litter from livestock to generate methane gas through anaerobic fermentation in biogas plants (DME, 2002). DME (2002) further states the need for assessment of the magnitude of agricultural waste (i.e. litter and manure) from cattle farms to potentially power biogas generators.

Even though South Africa is food-secure at a national scale, policies and inequalities enforced by previous regimes resulted in continuing food insecurity in some communities. Food security must be addressed within the context of other developmental issues that include provision of affordable and sustainable energy, rural and urban development, and water and sanitation to all the people living in the country (Wenhold et al., 2007). The objectives of this study were therefore to introduce biogas technology to an agricultural farming community in South Africa and provide farmers with in-depth knowledge on the operation and management of biodigesters, benefits and hazards relating to the use of biogas at household level. The study demonstrates how small-scale biogas technology can be used to improve energy and how it can be used to provide employment in the rural areas.

\section{Materials and methods \\ 2.1 Study area}

In this study, biodigester technology was introduced to a farming community in the Maluti-a-Phofung municipality in the Free State Province, South Africa (Figure 1) to improve the livelihoods of rural households in an environmentally sustainable manner. Maluti-a-Phofung has the highest poverty levels in both the Free State and the country (Buschke and Seaman, 2014). Provision of basic services is minimal, with the poverty rate of between $60-80 \%$ of the households below poverty level (Scott et al., 2005; HSRC, 2011). Agriculture is the main economic activity in this region, with mostly mixed livestock and crop farming (Moeletsi et al., 2015). 


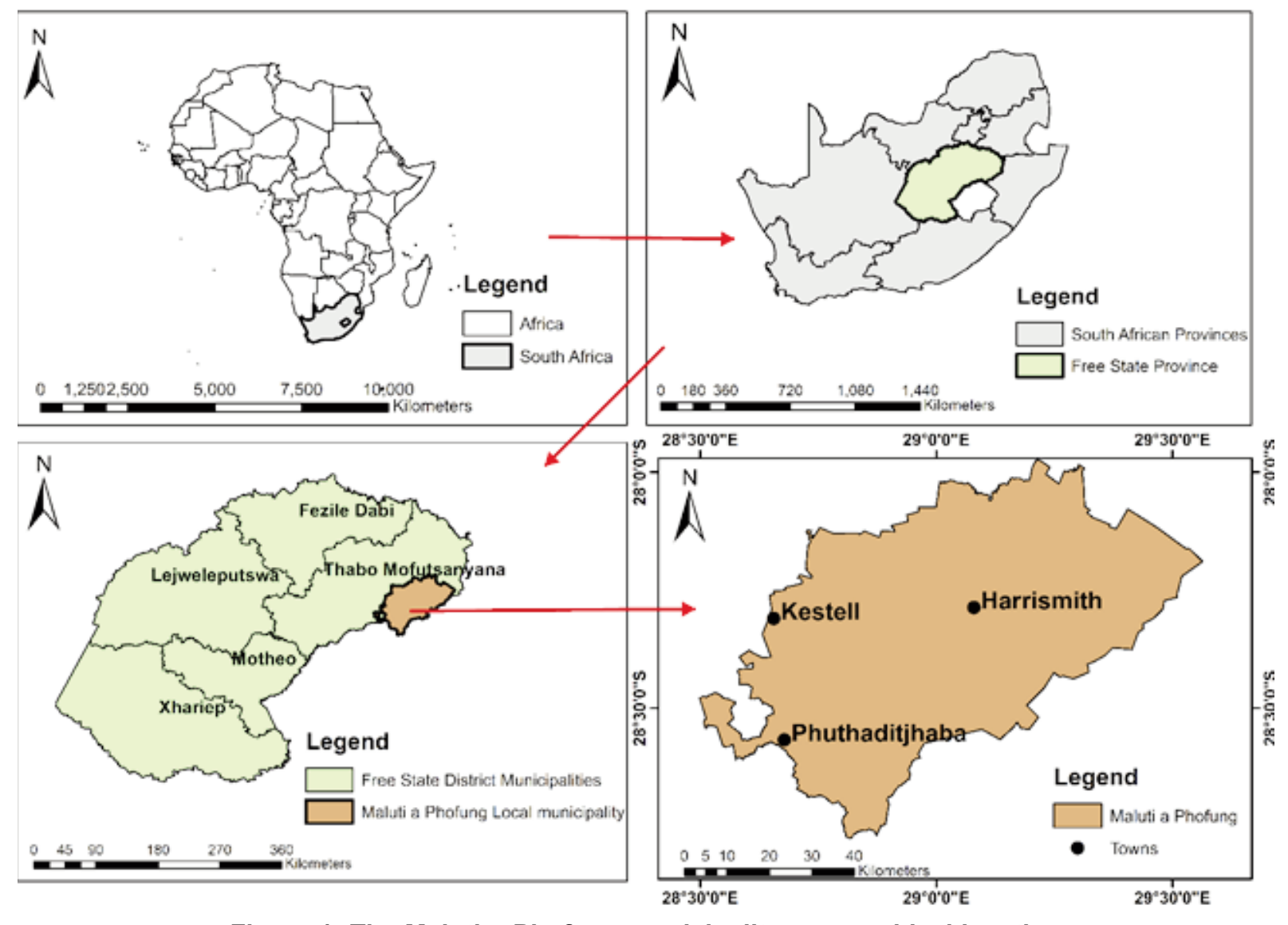

Figure 1: The Maluti-a-Phofung municipality geographical location

The region is characterised by hot summers and cold winters. Rainfall varies spatially and temporally; the mean annual rainfall varies from $628 \mathrm{~mm}$ in the northern parts to $1277 \mathrm{~mm}$ in the southern parts, while summer seasonal rainfall varies from $529 \mathrm{~mm}$ in the northern parts to $1161 \mathrm{~mm}$ in the southern parts (Moeletsi, 2010; Moeletsi et al., 2015). Maluti-a-Phofung experiences high temperatures in December, January and February and low temperatures in May, June, July and August. Mean monthly temperatures range from $16^{\circ} \mathrm{C}$ to $26^{\circ} \mathrm{C}$ while low temperatures range from $-1.0^{\circ} \mathrm{C}$ to $12.8^{\circ} \mathrm{C}$ (Figure 2). During winter months, temperatures can reach below freezing point resulting in frost and snowfall (Moeletsi and Tongwane, 2017).

\subsection{Methodology}

To enhance the rural farming community's adoption of biogas technology, the study was carried out in phases, as shown in Figure 3. In Phase 1, a diagnostic survey was conducted to determine the current energy requirements and sources of energy, to assess if farmers have enough cattle to meet the daily household biogas demand, and to evaluate if selected beneficiaries have enough resources (i.e. land, water and labour). In Phase 2, farmers and youths were trained to equip the local community with knowledge on bioenergy, feeding regimes and the maintenance of the biodigesters. In Phase 3, the trainees and the project team installed the biodi- gesters. In the final phase, monitoring and evaluation activities were undertaken to assess firstly the performance of the biogas technology and the farmers' satisfaction with the biogas technology.

\subsubsection{Diagnostic survey and situational analysis}

Before introducing the biogas project it was imperative to conduct a diagnostic survey in the study area, since an inadequate understanding of the community dynamics could lead to inappropriate interventions and thus resource wastage (Smith, 2006). Situational analysis was undertaken in and

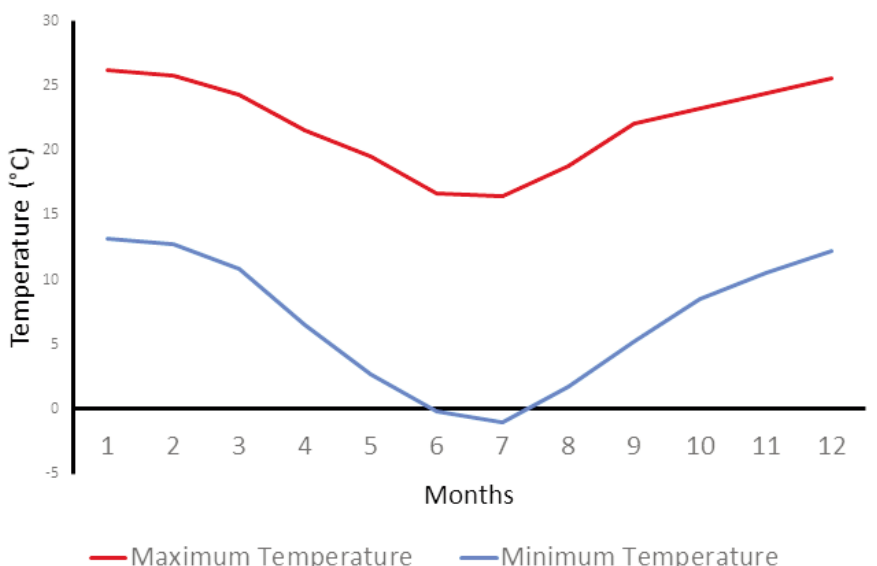

Figure 2: Average monthly minimum and maximum temperatures for Maluti-a-Phofung municipality 


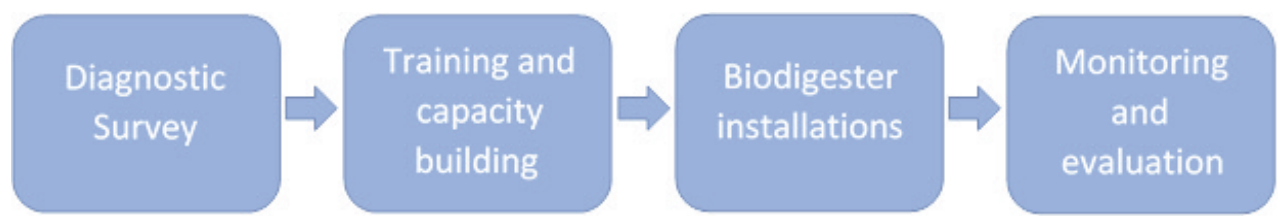

Figure 3: Study workflow for the introduction of biogas technology in Maluti-a-Phofung

around the farms of the Maluti-a-Phofung municipality during the inception of the study. Major objectives of the survey were: (1) to identify a tentative target group of farmers; (2) to collect, analyse, synthesise and interpret secondary information related to the target group; (3) to introduce biogas technology to farmers and show them how they can produce their own energy; (4) to determine the current energy needs of the farmers and their existing sources of energy; (5) to assess if farmers have enough cattle to meet daily household biogas digester demand; and (6) to assess if selected beneficiaries have sufficient resources (land, water and labour). The household energy analysis focused on determining the household energy use, energy use prioritisation and investigating the type and cost of the energy that is currently in use. This helped to identify energy consumptions that can be replaced by biogas and to assess ease of adoption of the new technology.

\subsubsection{Training and capacity building}

Several capacity building exercises took place during the life cycle of the study (September 2012 to June 2015). Table 1 shows several capacity building initiatives that were accomplished. This training was done by the project implementers from the Agricultural Research Council - Institute for Agricultural Engineering and Institute for Soil, Climate and Water.

Table 1: Training and capacity building initiatives

\begin{tabular}{lc}
\hline \multicolumn{1}{c}{ Title } & Target group \\
\hline $\begin{array}{l}\text { Introduction to bioenergy and } \\
\text { climate change }\end{array}$ & Farmers \\
Biodigester installation training & Farmers and youths \\
Maintenance of biodigesters & Farmers and youths \\
\hline
\end{tabular}

\subsubsection{Installation of biodigesters}

Two types of biogas digesters were considered: prefabricated and bricks-and-mortar. In this study, prefabricated digesters were deemed the most suitable, as they required minimum supervision and were easy to install. Experts and people with experience in building bricks-and-mortar digesters were not available in the project area. Thus, local youths could install prefabricated digesters after receiving brief training from the supplier of the technology. This created temporary job opportunities in the project area and skills transfer. Digging the biodigester pits, installation of the units and connections of the accessories by ten people took approximately 10 days in one site. Other sites with hard and rocky surfaces took more time.

Two types of prefabricated biogas digesters were used, in two phases. The digesters in the first batch were $3 \mathrm{~m}^{3}$ in size, and were coupled and installed parallel to each other, depending on the energy needs of the family. The digesters in the second batch were $6 \mathrm{~m}^{3}$ units. Other materials that accompanied the digesters include gas pipes, effluent pipes, pressure gauges, desulphuriser units and biogas stoves (Figure 4). Effluent in the form of biogas slurry was used to fertilise and water the farmers' gardens, which was an initiative to improve food security in their households.

\subsubsection{Monitoring and evaluation}

To assess the success of the project, the project managers or implementing team should undertake monitoring and evaluation (M\&E). Monitoring progress and evaluating impacts have long been considered important to ensure that investments are well spent and that the objectives are met (Guijt and Gaventa, 1998). M\&E activities in this study were undertaken in two ways. Firstly, project implementers monitored the performance of the biogas plants through unarranged household visits. Secondly, end-user questionnaires were used. The $M \& E$ activities of the digesters were undertaken in February 2014, April 2014, December 2014 and May 2015. Farmers were also interviewed through structured questionnaires to evaluate their satisfaction with the biogas technology. These evaluations also assessed whether farmer expectations in terms of the reliability of biogas supply by the technology, ease of operation, method of determining the available biogas and convenience of cooking with biogas and other benefits were satisfied. Feedback on the possible improvements and benefits of the technology was also obtained.

\section{Results and discussion \\ 3.1 Diagnostic survey}

The farmers who were interviewed comprised both subsistence and emerging smallholder farmers. The size of their farms ranged between 146 and 462 ha, less than a quarter of which was dedicated to crop farming. The 12 farms presented in Table 2 were chosen as beneficiaries of the project, based on the project requirements. All the chosen households kept cattle as the main form of livestock, with herd 


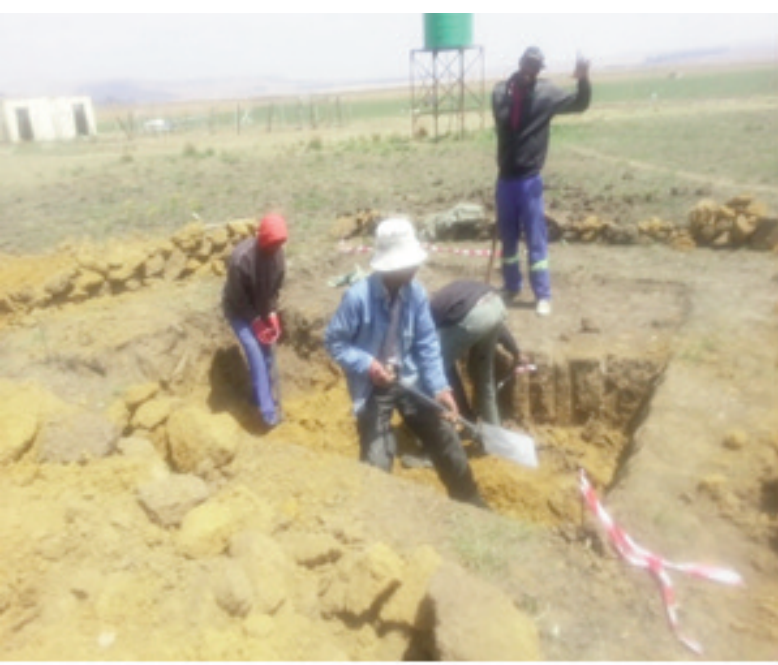

Excavation

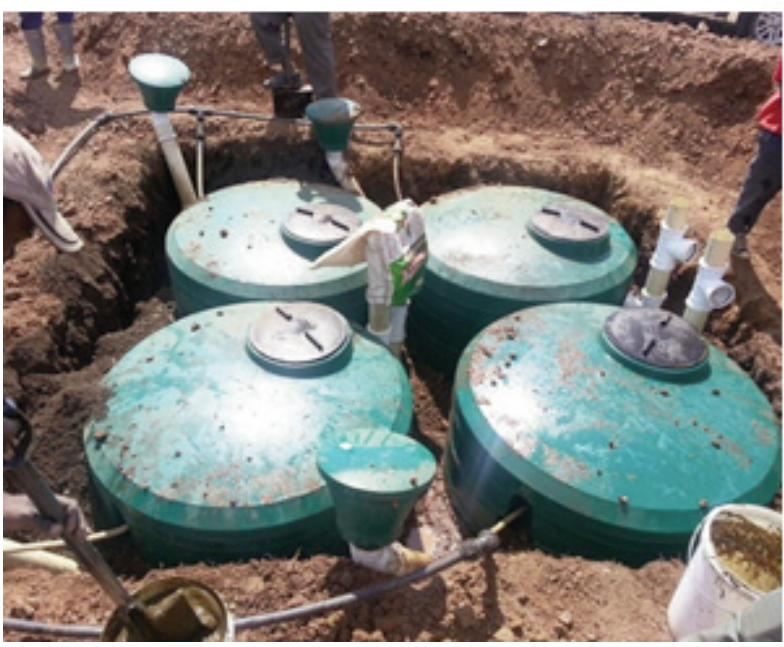

Backfilling

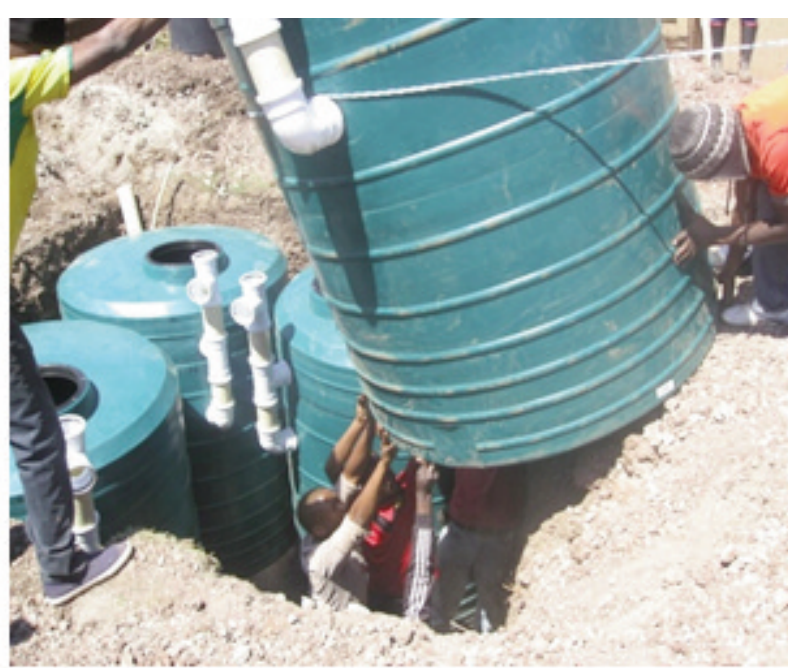

Placing digester tanks in side hole

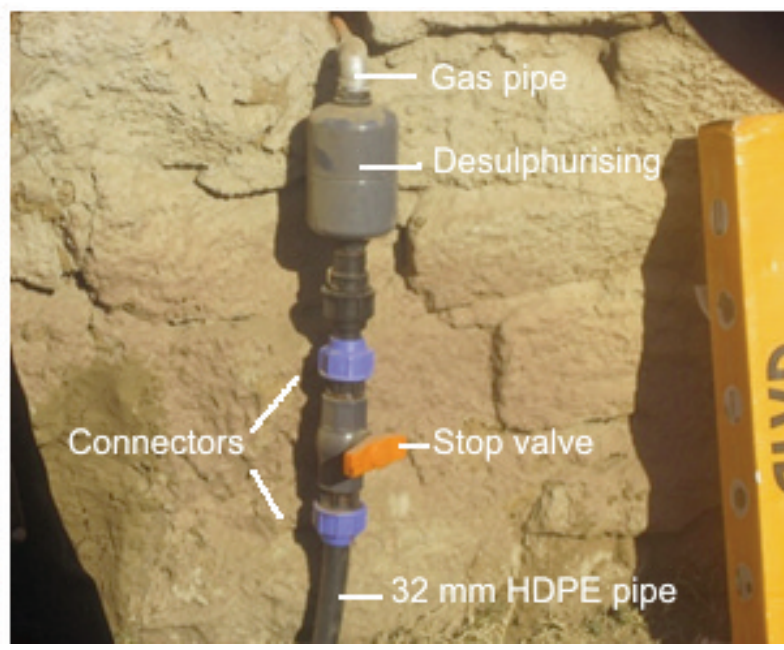

Gas pipes

Figure 4: Four installed units of $3 \mathrm{~m}^{3}$ biodigesters, gas pipes, effluent pipes, desulphuriser and biogas stove.

sizes ranging from 15 to 115 , producing enough dung to feed a small digester of 6-15 $\mathrm{m}^{3}$. Water availability is core to feeding the biodigester and all the chosen households had access to water throughout the year. On all 12 farms there was enough space around the house and not far from the kitchen to place the digester. It is important for the digester to be placed near the homestead for security reasons, to reduce piping costs and the chances of leakages, and to minimise pressure loss along the gas pipeline. At all the sites there were clear indications of available labour resources through either hired labourers or family members. This is important as work is required to collect the manure from the kraal, carry it to the digester, mix it with the water, and finally feed it into the digester. From the results obtained for energy demand used for domestic purposes, cooking was cited as the main energy consumer, followed by lighting, both of which are in use all year round. Cooking was mostly done using firewood (48\%), followed by LPG $(31 \%)$ and cow dung $(21 \%)$. On all of the farms, energy for refrigerators and lighting was entirely from LPG and candles respectively.

\subsection{Training and capacity building}

Training on bioenergy and climate change raised awareness of renewable energy sources and their importance for climate change mitigation. The benefits and disadvantages of this system were conveyed to the farmers.

Training equipped farmers and youths with the skills to install a prefabricated biodigester, the main components of training modules being: a) selection of the site, b) demarcation of the site, c) excavation and d) biodigester installation. The last stage was the feeding, maintenance and operation of the biodigester. Farmers were briefed on how to feed the digester, how to handle blockages and monitor biogas production.

\section{Selection of the site:}

Trainees were taught how to select the best site for the biodigester on the farm. Several factors should 
be considered, including the distance from the homestead, which must be as short as possible (Luer, 2010). The biodigester site should be close to a water source and the kraals to minimise the time spent collecting dung and mixing it with water. It is preferable that it should be on a downward slope from the kitchen to avoid the need to install a water drainage system, which would add additional costs to the installation (Energypedia, 2015).

Demarcation of the site:

Trainees were taught how to determine the correct measurements for the pit and mark out the area. The area to be marked out depends on the diameter of the digester unit as well as the number of tanks to be installed. The orientation of the tanks is important because feed inlet funnels and an effluent outlet should be positioned in such a way that they facilitate the feeding of the digester and collection of bioslurry. The position of the effluent outlet pipes, which should allow for gravity flow to the garden, is critical.

\section{Excavation:}

Farmers were taught the proper ways of digging the biodigester pit. The hole is excavated considering the height and depth of the digester. The importance of maintaining constant dimensions (length and width) for the hole during excavation was highlighted. Other factors to be considered during excavation were also discussed, including leaving space around the excavated hole to prevent the soil from falling back into it and providing enough space for the movement of wheelbarrows and people.

\section{Digester installation:}

The installation of the gas and effluent/bioslurry pipes was demonstrated through hands-on training. During the gas pipe installation training, emphasis was placed on making sure that all connections are airtight, to minimise gas leakage. Outlet pipes should be connected to a storage reservoir close to the vegetable garden (Figure 5).

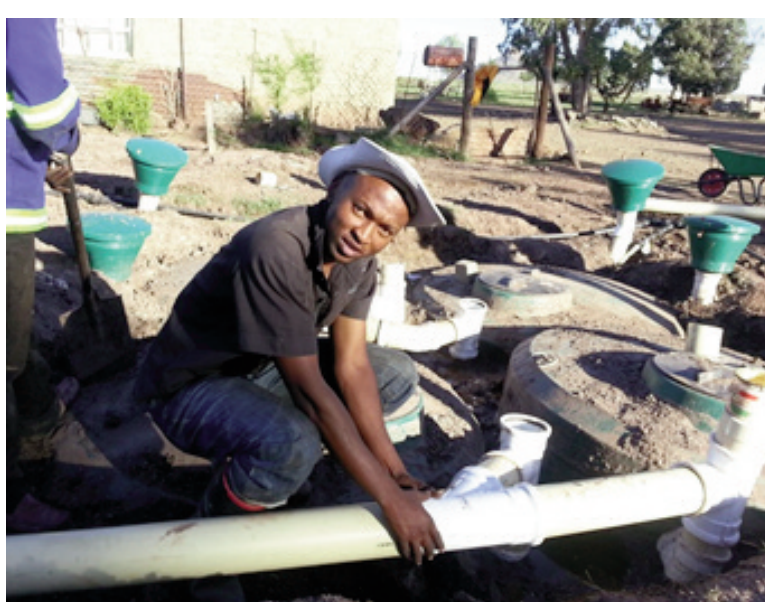

Figure 5: Trainee connecting effluent pipes
Feeding, maintenance and operation:

The biodigester maintenance training took place at the home of each beneficiary after the biodigester units had been installed. The main aim was to demonstrate to farmers how to manage a biogas digester. They were shown how to mix the animal dung with water and the frequency of feeding the biodigester. Beneficiaries were advised to mix water and animal dung at a 1:1 volume ratio when feeding the digester. All the farmers were advised to use clean water and utilise animal manure as a substrate. They were taught how to identify potential problems and were made aware of different types of feedstock that may be utilised. The trainees learnt how, what and when to feed the digester. It was strongly emphasised that it is critical to provide the digester with the correct quantity and quality of feed for it to operate correctly and sufficiently on a daily basis. The safety procedures that must be considered were also highlighted. These included installing appliance switches, detecting leakages, ensuring ventilation and avoiding fires near the digester and pipes. It was also emphasised that children should stay away from the digester tank, connected pipes and appliances.

\subsection{Installation of biodigesters}

The number of biodigester units installed at a homestead was based on two factors: the size of the family, which has a direct bearing on demand, and the minimum amount of biogas that can be generated daily by a single $3 \mathrm{~m}^{3}$ biodigester $\left(0.5 \mathrm{~m}^{3}\right.$ per day). A $6 \mathrm{~m}^{3}$ biodigester unit can produce around $1 \mathrm{~m}^{3}$ of biogas per day. All the homesteads chosen for this study had enough cow dung and available water to feed the biodigesters daily. It was therefore recommended that two biodigesters be installed for a family with a daily biogas demand of $1 \mathrm{~m}^{3}$ or less, while a family with a biogas demand of $1-2 \mathrm{~m}^{3}$ a day should have four $3 \mathrm{~m}^{3}$ units installed. The family size, daily biogas demand and number of biodigesters installed per household are shown in Table 2 . The installation of phase 1 biodigesters on farms 1 to 9 was completed in November 2013, and phase 2 installations on farms 10 to 12 in March 2014.

Bioslurry coming from the digester was used to fertilise and irrigate household gardens. These gardens produced vegetables which provided nutrition diversity and improved household food security (Wenhold et al., 2007). Through these gardens, farmers were able to save on their expenditure on vegetables. The approach used in this study demonstrated how these social challenges can be addressed simultaneously in the rural small-scale farming communities (Stats SA, 2012).

\subsection{Monitoring and evaluation}

After the biodigester units were installed, it took an average of eight weeks to produce biogas. The eval- 
Table 2: Number of biodigesters installed per household

\begin{tabular}{|c|c|c|c|c|c|c|}
\hline Farm & $\begin{array}{l}\text { Number of } \\
\text { cattle }\end{array}$ & $\begin{array}{l}\text { Family } \\
\text { members }\end{array}$ & $\begin{array}{c}\text { Estimated daily cooking } \\
\text { demand }\left(\mathrm{m}^{3} / \text { day }\right)\end{array}$ & $\begin{array}{c}\text { Tank size } \\
\left(\mathrm{m}^{3}\right)\end{array}$ & $\begin{array}{c}\text { Number of tanks } \\
\text { installed }\end{array}$ & $\begin{array}{l}\text { Capacity of bio- } \\
\text { digester unit }\left(\mathrm{m}^{3}\right)\end{array}$ \\
\hline \multicolumn{7}{|c|}{ Phase 1} \\
\hline$\overline{1}$ & 44 & 2 & 0.8 & 3 & 2 & 6 \\
\hline 2 & 80 & 2 & 0.8 & 3 & 2 & 6 \\
\hline 3 & 55 & 2 & 0.8 & 3 & 2 & 6 \\
\hline 4 & 44 & 3 & 1.2 & 3 & 4 & 12 \\
\hline 5 & 118 & 3 & 1.2 & 3 & 4 & 12 \\
\hline 6 & 39 & 5 & 2 & 3 & 4 & 12 \\
\hline 7 & 49 & 5 & 2 & 3 & 4 & 12 \\
\hline 8 & 90 & 5 & 2 & 3 & 4 & 12 \\
\hline 9 & 32 & 9 & 3.6 & 3 & 4 & 12 \\
\hline \multicolumn{7}{|c|}{ Phase 2} \\
\hline$\overline{10}$ & 53 & 2 & 0.8 & 6 & 1 & 6 \\
\hline 11 & 28 & 3 & 1.2 & 6 & 1 & 6 \\
\hline 12 & 13 & 5 & 2 & 6 & 1 & 6 \\
\hline
\end{tabular}

uation of phase 1 biodigesters started in February 2014 and phase 2 biodigesters in May 2015. At the first three evaluations only eight sites had been completed (phase 1), and the biogas produced on farms 3, 8 and 9 was enough to allow the households to cook consistently for more than an hour (Table 3). Major cooking was done mainly in the morning and in the evening and biogas production was enough for these activities. This was mostly attributed to adherence to the digester feeding ratios, and the frequency with which the substrate was fed into the digester units. On farms 1, 2, 4, 5, 6 and 7 , biogas production was not at the desired level, mainly due to irregular feeding, feeding the digester at a low rate and blockages of the biodigesters due to wrong feeding ratios. At some sites where the biodigesters were not functioning well, the kraals were relatively far from the homesteads which required extra work to collect the feedstock. This might be the main reason that those households failed to embrace the technology due to perceived high labour requirements. The units that were installed between November 2014 and March 2015 (phase 2) were mostly working well at their first evaluation in May 2015. The general observation was that the initial units of $3 \mathrm{~m}^{3}$ (digesters installed in phase 1 ) required a high level of maintenance compared to the $6 \mathrm{~m}^{3}$ units that were installed at some of the sites. The parallel installation of more than one $3 \mathrm{~m}^{3}$ units required too many connections, such as inter-compartment, inlet, gas pipe and effluent connections. This led to high blockage problems and eventually reduced functionality of the biodigester, while the $6 \mathrm{~m}^{3}$ units had minimal connectivity (effluent pipes and gas pipes). In phase 2 , one unit of $6 \mathrm{~m}^{3}$ tanks was installed on

Table 3: Evaluation of biogas production on the farms

\begin{tabular}{lllll}
\hline Farm & 10-11 February 2014 & 8-10 April 2014 & 3-5 December 2014 & 28-29 May 2015 \\
\hline 1 & \multicolumn{1}{l}{ Phase 1 } & & \\
2 & $\mathrm{~A}$ & $\mathrm{P}$ & $\mathrm{P}$ & $\mathrm{P}$ \\
3 & $\mathrm{P}$ & $\mathrm{P}$ & $\mathrm{P}$ & $\mathrm{P}$ \\
4 & $\mathrm{~A}$ & $\mathrm{~A}$ & $\mathrm{P}$ & $\mathrm{A}$ \\
5 & - & - & $\mathrm{P}$ & $\mathrm{P}$ \\
6 & - & - & $\mathrm{E}$ & $\mathrm{A}$ \\
7 & $\mathrm{~A}$ & $\mathrm{E}$ & $\mathrm{A}$ & $\mathrm{P}$ \\
8 & $\mathrm{P}$ & $\mathrm{P}$ & $\mathrm{A}$ & $\mathrm{P}$ \\
9 & $\mathrm{P}$ & $\mathrm{P}$ & $\mathrm{A}$ & $\mathrm{A}$ \\
\hline & $\mathrm{A}$ & $\mathrm{E}$ & & $\mathrm{A}$ \\
\hline 10 & - & & - & $\mathrm{A}$ \\
11 & - & - & - & $\mathrm{A}$ \\
\hline
\end{tabular}

Biogas production: $\mathrm{P}=$ Poor $(<1$ hour of cooking), $\mathrm{A}=$ Average (1-3 hours of cooking), $\mathrm{E}=$ Excellent ( $>3$ hours of cooking) 
farms 10, 11 and 12 which gave an improved performance, allowing users to cook for more than an hour daily.

It was critical to assess the users' feelings towards the biogas technology, especially as it was a pilot project aimed at improving rural livelihoods and environmental concerns. The operation and performance of biodigesters, as seen by the users, was useful for engineers who design the plants, manufacturers and project funders who assessed whether the biodigesters are a worthwhile investment, and for policy makers. The results of the enduser satisfaction showed that most of the farmers ( 9 out of 12) were satisfied with the installed biodigesters on the farms, while three of the farmers indicated that they were not content with the technology. Eight of the 12 households stated that $80 \%$ of their cooking needs were met in summer. In the four households $(1,2,5$ \& 9) that were not satisfied with the technology, it was realised that their biodigesters were not functioning well because of negligence and blockages, as described above.

It was interesting to note that all the households showed that biogas production in the winter months dropped drastically to levels that made it not worth the effort of feeding the biodigester. In summer, most of the households can utilise the biogas for over one hour, with two households (10 and 12) claiming that they could cook with it for more than two hours in the evening. The variation in biogas production was attributed to the large climate difference in summer and winter months. High temperatures favour biogas production while temperatures below $10^{\circ} \mathrm{C}$ tend to lower it (Moeletsi et al., 2015).

\section{Opportunities and challenges of small- scale biogas production in South Africa}

One of the problems that South Africa faces is the assurance of reliable energy in rural areas. Farms owned by resource-poor individuals are highly energy insecure and rely on candles, firewood and animal dung as sources of energy. The rapid rate of forest destruction and low rate of reforestation have reduced the availability of firewood. It is thus important to introduce alternative sources of energy for farming communities. These sources must be environmentally friendly and sustainable. Biogas technology provides numerous opportunities that can be explored, as well as challenges that need to be addressed to ensure that the technology meets societal and environmental needs (Surendra et al., 2014). The biogas technology can also be incorporated into a crop-livestock-bioenergy system for sustainable production of food and energy. This approach has an advantage since traditionally African people practise mixed farming, which involves the production of both crops and animals on three types of land, namely residential, arable and commonage (Abdu-Raheem and Worth, 2011).

Even though biogas technology is one of the cheapest renewable technologies for rural livelihoods, it is still expensive for resource-poor communities. In South Africa, erecting or installing a 6$10 \mathrm{~m}^{3}$ prefabricated biodigester costs between ZAR 8000 (>USD 500) and ZAR 80000 (>USD 5 000 ), depending on the material used and the size of the biodigester (Surendra et al., 2014; Moeletsi et al., 2015; Rajendran et al., 2012). The cost of a bricks-and-mortar biodigester can be slightly lower. These costs are too high for most people living in rural areas, who are unemployed and depend on government grants to meet their daily needs. Thus, there is a need for government departments, agencies and private organisations to invest in rural biogas plants to secure the energy needs of the poor and rural communities. Introducing renewable energy for rural farming communities in South Africa is a better solution than putting them on the national electricity grid, which is fossil-fuel-intensive. Electricity can be substituted by biogas technology in rural farming set-ups, which produces clean energy over and above its affordability. This is becoming ever more necessary as grid electricity tariffs in South Africa have been increasing at a rate exceeding $16 \%$ per annum since 2010 , meaning that electricity costs will choke small-scale farmers, resulting in reduced cash flow and farm functionality.

Biogas production requires continual feeding of organic matter (animal manure in this case study). The results showed that the small-scale digesters performed well in households that were kraaling their cows. This was one of the significant factors that affected the adoption of the technology in the region. The issue of the distance from the kraal to the kitchen was also crucial in the success of the technology. The further from the kraal to the digester (installed close to the kitchen), the higher the chances of defaulting on the feeding of the digester, resulting in a failure of the system. This was due to increased labour requirements for collection of animal dung. In addition, water is a scarce commodity in South Africa. Lack of investment in rural water supply has a direct impact on the success of biogas digesters, since in most rural areas a constant water supply is a challenge. Most households do not have their own water supply in rural areas.

In winter, biogas production at all the sites dropped significantly. This was attributed to the extremely low temperatures experienced in this region, usually below $0^{\circ} \mathrm{C}$ in the morning and $20^{\circ} \mathrm{C}$ in the afternoon. According to Dobre et al. (2013), biogas can be produced at temperatures exceeding $10^{\circ} \mathrm{C}$, with optimal production occurring at around $35^{\circ} \mathrm{C}$. A heating system and insulation can be a solution to the low biogas production in winter, but 
would be expensive and would hamper the economic viability of the system (APCAEM, 2007). This creates a problem that needs serious intervention to allow financially feasibility in rural areas. Fluctuating biogas production makes unheated biodigesters unsuitable for the eastern Free State region, thus having a negative impact on the sustainability of the technology in the area.

Small-scale biodigesters contribute to climate change mitigation and adaptation, with mitigation realised through reduced deforestation and captured methane emissions. According to Surendra et al. (2014), the greenhouse gas emissions reduction potential of biogas technology can be realised through manure management, the substitution of traditional fuels (such as firewood, coal, electricity, candle and kerosene) and the substitution of composite fertiliser. Deforestation is reduced through less wood being collected for cooking, while methane emissions from manure management can be reduced by utilising biodigesters. Replacing and complementing conventional synthetic fertilisers with nutrient-rich biodigester slurry offers a means for resource-strapped rural farmers to mitigate and adapt to climate change (Roubík et al., 2018).

Despite the numerous successes and documented evidence of the benefits of small-scale biodigesters worldwide, the uptake of biodigesters in South African rural communities remains low. This can be attributed to poor promotion of the technology, communities' lack of awareness of biodigesters, lack of a variety of choices for consumers, and a lack of skilled personnel to construct the units. The absence of research data on the operation and performance of biodigesters under South African conditions is also a contributing factor. Bond and
Templeton (2011) also attributed people's failure to embrace biogas technology in developing countries to low rates of technology transfer (a capacity building issue), longevity of the promoted technology, and people's perception that biodigesters are labour-intensive and require an intensive maintenance plan.

\section{Conclusions}

The study achieved its main objective of promoting the adoption of biodigesters among rural farmers in the Maluti-a-Phofung municipality, South Africa. This was undertaken by understanding the local conditions through a reconnaissance survey during the inaugural stages of the study. This was followed by training farmers in biogas technology, feedstock, the feeding regime and maintenance of the biodigesters. Biodigesters were also installed and monitored. Generally, most of the farming households that participated in the study accepted the technology, even though challenges were encountered such as unit blockages and a low yield of biogas in winter.

\section{Acknowledgements}

The study was funded by the Department of Agriculture, Forestry and Fisheries. The authors are grateful to farmers in the Maluti-a-Phofung municipality for their cooperation while undertaking trials on their farms.

\section{Author roles}

The manuscript was prepared by Moses Nape, Primrose Magama, Mphethe Tongwane, Mokhele Moeletsi and Vuyo Mliswa. Matiga Motsepe, Seneo Madikiza and Mpho Nakana assisted in the data collection.

\section{References}

Abdu-Raheem, K.A. and Worth, S.H. 2011. Household food security in South Africa: Evaluating extension's paradigms relative to the current food security and development goals, South African Journal of Agricultural Extension 39(2): 91-103.

Asian and Pacific Centre for Agricultural Engineering and Machinery [APCAEM]. 2007. Recent developments in biogas technology for poverty reduction and sustainable development, United Nations Economic and Social Commission for Asia and the Pacific.

Bensah, E. and Brew-Hammond, C.A. 2010. Biogas technology dissemination in Ghana: history, current status, future prospects, and policy significance. International Journal of Energy and Environment 1(2): 277-294.

Bond, T. and Templeton, M.R. 2011. History and future of domestic biogas plants in the developing world. Energy for Sustainable Development 15: 347-354. https://doi.org/10.1016/j.esd.2011.09.003

Buschke, F.T. and Seaman, M.T. 2014. Golden Gate Highlands National Park: Killing the goose laying golden eggs? Comment on Taru et al. 2013. South African Journal of Science 11(7-8): 1-2. https://doi.org/10.1590/sajs.2014/a0075

Department of Minerals and Energy [DME]. 2002. White paper on the promotion of renewable energy and clean energy development. Part one - promotion of renewable energy. Available at https://www.gov.za/sites/default/files/gcis_document/201409/rewp2208022.pdf, last viewed 20/05/2017.

Department of Minerals and Energy [DME]. 2015. State of Renewable Energy in South Africa, Available at http://www.energy.gov.za/files/media/Pub/State-of-Renewable-Energy-in-South-Africa.pdf, last viewed 21/08/2018.

Department of Presidency [DOP]. 2012. National Development Plan 2030. Available at https://www.gov.za/issues/national-development-plan-2030, last viewed 12/09/2018. 
Dobre, P., Nicolae, F. and Matei, F. 2013. Main factors affecting biogas production - an overview. University of Agronomic Sciences and Veterinary Medicine, Bucharest, Romania.

Eberhard, A., Kolker, J. and Leigland, J. 2014. South Africa's Renewable Energy IPP Procurement Programme: Success factors and lessons. Available at http:/www.gsb.uct.ac.za/files/PPIAFReport.pdf, last viewed 04/06/2019.

Energypedia. 2015. Piping systems for biogas plants. Available at https://energypedia.info/wiki/Piping_Systems_for_Biogas_Plants, last viewed 06/06/2019.

Guijt, I. and Gaventa, J. 1998. Participatory monitoring and evaluation: learning from change. Institute of Development Studies (IDS), UK. IDS Policy Briefings, (12). https://doi.org/10.3362/9781780441214.017

Human Sciences Research Council [HSRC]. 2011. Poverty. Report available at http:/www.hsrc.ac.za/uploads/pageContent/2706/Part\%208_FET\%20audit\%20\%20Client\%20report\%20Section\%204\%20poverty\%20final\%20Part\%201\%20Aug\%202011\%20pp.118-124.pdf, last viewed 29/04/2019.

Luer, M. 2010. Installation manual for low-cost polyethylene tube digesters. Report available at https://energypedia.info/images/1/19/Low_cost_polyethylene_tube_installation.pdf, last viewed 06/06/2019.

Moeletsi, M.E. 2010. Agroclimatological risk assessment of rain-fed maize production for the Free State Province of South Africa, PhD thesis, Department of Soil, Crop and Climate Sciences, University of the Free State, Bloemfontein, South Africa. https://doi.org/10.4314/wsa.v38i5.17

Moeletsi, M.E., Nape, K.M., Magama, P., Masupha, E.T., Tongwane, M.I., Malaka, S.F., Lebotsa, M., Ncokazi, M., Nakana, P.M., Melato, L., Matela, T., Mukwada, G., Mazibuko, S.M., Motsepe, M., Madikidza, S., Makananisa, F., Muntswu, M., Gegana, M. and Chabalala, Z. 2015. Mitigation and adaptation to climate variability and change in the Thabo Mofutsanyane District (Free State Province, South Africa): A multi-disciplinary approach through integrated crop-livestock system. Report for the Department of Agriculture, Forestry and Fisheries, Pretoria, South Africa.

Moeletsi, M.E. and Tongwane, M.I. 2017. Spatiotemporal variation of frost within growing periods. Advances in Meteorology 2017, Article ID 5472869, 11 pages. https://doi.org/10.1155/2017/5472869

Organisation for Economic Cooperation and Development [OECD]. 2012. Linking renewable energy to rural development. OECD Green Growth Studies, OECD, Paris. https://doi.org/10.1787/9789264180444-1-en

Rajendran, K., Aslanzadeh, S. and Taherzadeh, M.J. 2012. Household biogas digesters - a review. Energies 5: 29112942. https://doi.org/10.3390/en5082911

Roubík, H, Mazancová, J., Le Dinh, P., Dinh Van, D. and Banout, J. 2018. Biogas quality across small-scale biogas plants: A case of central Vietnam. Energies 11: 1794. https://doi.org/10.3390/en11071794

Rupf, G.V., Bahri, P.A., De Boer, K. and McHenry, M.P. 2015. Barriers and opportunities of biogas dissemination in Sub-Saharan Africa and lessons learned from Rwanda, Tanzania, China, India, and Nepal. Renewable and Sustainable Energy Reviews 52: 468-476. https://doi.org/10.1016/j.rser.2015.07.107

Scott, V.E., Chopra, M., Conrad, L. and Ntuli, A. 2005. How equitable is the scaling up of HIV service provision in South Africa? South African Medical Journal 95: 109-113.

Sibisi, N.T. and Green, J.M. 2005. A floating dome biogas digester: perceptions of energising a rural school in Maphephetheni, KwaZulu-Natal. Journal of Energy in Southern Africa 16(3): 45-52. https://doi.org/10.17159/2413-3051/2005/v16i3a3115

Smith, H.J. 2006. Development of a systems model facilitating action research with resource-poor farmers for sustainable management of natural resources. PhD thesis, University of the Free State, Bloemfontein, South Africa.

Stats SA. 2012. Food security and agriculture: In depth analysis of the general household survey data. Statistics South Africa. Available at http://www.statssa.gov.za/, last viewed 12/05/2017.

Surendra, K.C., Takara, D., Hashimoto, A.G. and Khanal, S.K. 2014. Biogas as a sustainable energy source for developing countries: opportunities and challenges. Renewable and Sustainable Energy Reviews 31: 846-859. https://doi.org/10.1016/j.rser.2013.12.015

United Nations Conference on Trade and Development (UNCTD). 2010. Renewable energy technologies for rural development.

Warget, D. 2009. Biogas in developing rural areas. LTH, Lund University.

Wenhold, F.A.M., Faber, M., van Averbeke, W., Oelofse, A., van Jaarsveld, P., Jansen van Rensburg, W.S., van Heerden, I. and Slabbert, R. 2007. Linking smallholder agriculture and water to household food security and nutrition. Water SA. 33(3). https://doi.org/10.4314/wsa.v33i3.49111

Yuen, K.S.E. 2014. An analysis of renewable energy prices in the South African Renewable Energy Independent Power Producer Procurement Programme. MSc thesis, Paris School of International Affairs. 